\title{
PEMBELAJARAN KONTEKSTUAL PADA MATA KULIAH RESTORAN UNTUK MENINGKATKAN KOMPETENSI MAHASISWA PENDIDIKAN TEKNIK BOGA
}

\author{
Prihastuti Ekawatiningsih \\ Jurusan Pendidikan Teknik Boga FT UNY \\ Email: prihastuti@uny.ac.id
}

\begin{abstract}
The objective of this study was to improve the quality of learning in the subject of Restaurant indicated by the improvement of learning activities and the students' achievement through the application of contextual learning in the department of Hospitality Engineering. This study is categorised into classroom action research. The data was analysed descriptively. The results revealed: (1) The students were more active in the learning process as indicated by the improvement of the learning activities proved by the following data: in the first cycle, the percentages of the students who pay attention to the lecturers' explanation, answer questions by providing daily life examples, express opinions, and conduct presentations were $47.5 \%$, 25\% 12.5\%, 15\% respectively, while in the second cycle, they were $52.5 \%, 12.5 \%, 50 \%, 10 \%$ respectively. (2) The students demonstrate better mastery of the materials as indicated by the following data: the percentages of the students who achieved very good, good, fair and poor scores were 10\%, 50\%, 15\% and 25\% respectively while in the second cycle the students who achieved very good and good scores were $62.5 \%$ and $37.5 \%$ respectively.
\end{abstract}

Keywords: contextual learning, student competence, the subject of restaurants

\begin{abstract}
ABSTRAK
Tujuan penelitian ini untuk meningkatkan kualitas pembelajaran mata kuliah Restoran yang ditunjukkan dengan peningkatan aktivitas dan prestasi belajar mahasiswa Prodi PT Boga melalui penerapan pembelajaran kontekstual. Penelitian ini merupakan penelitian tindakan kelas. Analisis data yang digunakan analisis deskriptif. Hasil penelitian menunjukan: (1) keaktifan mahasiswa pada pembelajaran Restoran meningkat, terlihat dari data siklus I, mahasiswa memperhatikan penjelasan dosen sebanyak 47,5\%, mahasiswa menjawab pertanyaan dengan memberikan contoh dalam kehidupan sehari-hari sebanyak $25 \%$, mahasiswa mengemukakan pendapat sebanyak $12,5 \%$ dan mahasiswa melakukan presentasi sebanyak $15 \%$, pada siklus II keaktifan belajar mahasiswa memperhatikan penjelasan dosen meningkat sebesar 52,5\%, menjawab pertanyaan meningkat $12,5 \%$, mengemukakan pendapat meningkat $50 \%$, dan kegiatan presentasi meningkat $10 \%$; 2) tingkat pengetahuan mahasiswa terhadap materi pembelajaran Restoran meningkat, terlihat dari data siklus I, 10\% mahasiswa memperoleh nilai amat baik, 50\% mahasiswa memperoleh nilai baik, 15\% mahasiswa memperoleh cukup, dan $25 \%$ mahasiswa memperoleh nilai kurang, pada siklus II, hasil belajar mahasiswa pada siklus II adalah $62,5 \%$ mahasiswa mendapatkan nilai amat baik dan 37,5\% mahasiswa mendapatkan nilai baik.
\end{abstract}

Kata kunci: kompetensi mahasiswa, mata kuliah restoran, pembelajaran kontekstual

\section{PENDAHULUAN}

Program Studi Pendidikan Teknik Boga (Prodi PT Boga) merupakan salah satu program studi yang terdapat di Jurusan Pendidikan Teknik Boga dan Busana, Fakultas Teknik, Universitas Negeri Yogyakarta. Salah satu tujuan Prodi PT Boga adalah menyelenggarakan pendidikan profesional guru Sekolah Menengah Kejuruan (SMK) bidang Tata Boga sehingga dapat menghasilkan calon guru SMK bidang
Tata Boga yang profesional dan mempunyai kompetensi tinggi sesuai dengan sosok utuh kompetensi guru yang profesional seperti yang dituangkan dalam Naskah Akademik Revitalisasi Pendidikan Profesional Guru, yaitu (a) Learning to do yang dicerminkan sebagai kemampuan untuk menampilkan unjuk kerja pembelajaran yang mendidik, (b) Learning to know yang dicerminkan sebagai kemampuan meningkatkan 
profesionalitas secara berkelanjutan, (c) Learning to live together yang dicerminkan sebagai kemampuan menghormati keragaman budaya dan kemampuan memelihara jaringan kerjasama untuk mendukung kinerja pendidikan nasional, dan (d) Learning to be yang dicerminkan sebagai integritas profesional yang tangguh (Depdiknas, 2007).

Keluhan dari pemakai lulusan lembaga pendidikan termasuk Lembaga Pendidikan Tenaga Kependidikan (LPTK) terutama adalah lulusan yang masih belum sesuai dengan harapan dan tuntutan dunia kerja. Lulusan lembaga pendidikan kurang mempunyai daya saing di lingkungan kerja, kurangnya daya inovasi serta kemampuan untuk dilatih kembali. Hal ini dapat dirunut karena lulusan kurang dibekali dengan kemampuan belajar tentang bagaimana belajar (learning how to learn). Pendidikan yang diperoleh lebih pada kemampuan learning to do dan kurang membekali dengan kemampuan learning to know, learning to live together, learning to be dan learning throughout life. Salah satu faktor yang mendasar dan terkait langsung dengan mutu lulusan pendidikan tinggi adalah proses pembelajaran yang masih terpusat pada dosen dan kurang memberdayakan peserta didik.

Mutu pendidikan dapat terwujud jika proses pembelajaran diselenggarakan secara efektif, artinya proses belajar mengajar (PBM) dapat berlangsung secara lancar, terarah dan sesuai dengan tujuan pembelajaran. Dalam struktur kurikulum 2009 Prodi PT Boga, mata kuliah Restoran merupakan salah satu mata kuliah pilihan bagi mahasiswa semester 6 dengan 3 SKS praktik yang ditawarkan pada semester genap. Kompetensi mahasiswa yang diharapkan setelah menempuh mata kuliah Restoran yang terdapat dalam silabus adalah (1) Mendayagunakan potensi diri untuk berwirausaha di bidang restoran; (2) Menerapkan prinsip-prinsip manajemen dalam usaha restoran; (3) Menerapkan keterampilan produksi dalam usaha restoran; (4) Menerapkan keterampilan pelayanan dalam bidang restoran;
(5) Menganalisis peluang usaha dalam bidang restoran; dan (6) Melakukan kegiatan pemasaran produk restoran dan implementasi business plan.

Mata kuliah Restoran merupakan mata kuliah pilihan bagi mahasiswa Prodi PT Boga sebagai kulminasi mata kuliah lain yang berkaitan dengan produksi makanan dan pelayanan jasa sehingga dapat memenuhi kebutuhan konsumen. Dengan demikian mata kuliah Restoran dapat digunakan sebagai salah satu bekal bagi mahasiswa Prodi PT Boga dalam menyiapkan produk makanan dan sekaligus melayani konsumen secara langsung.

Berdasarkan pengamatan selama mengajar mata kuliah Restoran dari tahun 2009 sampai dengan sekarang, nampak bahwa mahasiswa Prodi PT Boga masih kesulitan mengaplikasikan rancangan bisnis yang sudah dibuat secara komprehensif dalam praktik. Mahasiswa masih menganggap mata kuliah Restoran sebagai mata kuliah praktik dan tidak berkaitan dengan mata kuliah produksi dan pelayanan makanan yang sudah diperoleh semester sebelumnya. Dalam penerapan rancangan bisnis mahasiswa kesulitan mencari tamu atau konsumen. Oleh karena itu, diperlukan strategi pembelajaran mata kuliah Restoran yang tepat agar mahasiswa dapat memenuhi kompetensi yang diharapkan.

Salah satu strategi pembelajaran pada mata kuliah Restoran yang layak untuk diujicobakan adalah pendekatan kontekstual. Pendekatan kontekstual (Contextual Teaching and Learning / CTL) merupakan konsep belajar yang membantu dosen mengaitkan antara materi dan dunia nyata mahasiswa sehingga mendorong mahasiswa menghubungkan antara pengetahuan yang dimiliki dengan penerapan pengetahuan tersebut dalam masyarakat. Pembelajaran Praktik Restoran merupakan salah satu sumber belajar yang dapat membantu mahasiswa berlatih menerapkan semua kompetensi yang telah dipelajari sebelumnya dalam kehidupan nyata. Mata kuliah Restoran bagi mahasiswa Pendidikan Teknik Boga, Jurusan Pendidikan Teknik Boga dan Busana, Fakultas Teknik, Universitas Negeri Yogyakarta merupakan mata 
kuliah kulminasi praktik, menghasilkan produk dan jasa pelayanan makanan.

Salah satu pendekatan yang diperkirakan mampu memecahkan masalah tersebut dan layak diujicobakan adalah pembelajaran mata kuliah Restoran dengan menerapkan pembelajaran kontekstual. Penelitian ini bertujuan untuk meningkatkan kualitas pembelajaran mata kuliah Restoran yang ditunjukkan dengan peningkatan aktivitas dan prestasi belajar mahasiswa Prodi PT Boga melalui penerapan pembelajaran kontekstual. Mata Kuliah Restoran adalah mata kuliah praktik yang mempunyai bobot 3 sks atau setara dengan 3x100 menit.

Sebagai prasyarat mengikuti mata kuliah ini mahasiswa harus sudah menguasai berbagai pengetahuan dan keterampilan produktif antara lain Teknik Pengolahan Makanan Indonesia, Teknik Pengolahan Makanan Oriental, Teknik Pengolahan Makanan Kontinental, Tata Hidang I dan Manajemen Usaha Boga. Disamping itu mata kuliah teori seperti kewirausahaan, Pemasaran, Akuntansi Usaha dan Pengetahuan Bahan Makanan. Melihat begitu banyak prasyarat yang ada, lebih tepat Mata Kuliah ini disebut sebagai mata kuliah terapan, sehingga menuntut kompetensi-kompetensi teknis dalam bidang produksi dan layanan dan juga kompetensi manajerial. Kompetensi teknis tersebut dapat dirumuskan menjadi enam kompetensi yang harus dikuasai oleh mahasiswa setelah mengikuti mata kuliah Restoran. Keenam kompetensi tersebut adalah sebagai berikut: (1) mendayagunakan potensi diri untuk berwirausaha bidang restoran; (2) menerapkan prinsip-prinsip manajemen dalam usaha restoran; (3) menerapkan keterampilan produksi dalam usaha restoran; (4) menerapkan keterampilan pelayanan dalam bidang restoran; (5) menganalisis peluang usaha dalam bidang restoran; dan (6) melakukan kegiatan pemasaran produk restoran.

Berdasarkan uraian di atas, dapat terlihat bahwa kompetensi yang harus dikuasai mahasiswa dalam menempuh Mata Kuliah Restoran sangat banyak dan kompleks. Untuk itu diperlukan pula proses atau metode penilaian yang tepat agar penguasaan kompetensi maupun unit - unit kompetensi dapat terukur dengan baik. Dengan karakteristik tersebut, maka dalam penelitian ini dicoba alternatif pembelajaran dengan menggunakan model CTL. Model ini sangat cocok diterapkan pada mata kuliah yang mempunyai tuntutan - tuntutan kompetensi yang cukup kompleks, khususnya dalam meningkatkan kemampuan soft skill mahasiswa. Penerapan model CTL ini diharapkan dapat memperbaiki kualitas pembelajaran dalam mata kuliah Restoran

Pembelajaran kontekstual didasarkan pada hasil penelitian John Dewey (1916) yang menyimpulkan bahwa siswa akan belajar dengan baik jika apa yang dipelajari terkait dengan apa yang telah diketahui dan dengan kegiatan atau peristiwa yang akan terjadi di sekelilingnya. Toharudin (2005) menjelaskan pembelajaran ini menekankan pada daya pikir yang tinggi, transfer ilmu pengetahuan, mengumpulkan dan menganalisis data, memecahkan masalahmasalah tertentu baik secara Hindividu maupun kelompok. Pendekatan kontekstual (Contextual Teaching and Learning (CTL) merupakan konsep belajar yang membantu guru atau dosen mengaitkan antara materi yang diajarkan dengan situasi dunia nyata siswa dan mendorong siswa membuat hubungan antara pengetahuan yang dimiliki dengan penerapan dalam kehidupan sebagai anggota keluarga dan masyarakat. (Depdiknas, 2004). Dengan konsep itu, hasil pembelajaran diharapkan lebih bermakna bagi siswa. Proses pembelajaran berlangsung alamiah dalam bentuk kegiatan siswa bekerja dan mengalami, bukan transfer pengetahuan dari guru ke siswa. Strategi dalam pembelajaran lebih dipentingkan daripada hasil (Direktorat Pembinaan SMP, 2006). Perbedaan pendekatan pembelajaran kontekstual dengan pendekatan tradisional disajikan pada Tabel 1 di bawah ini. 
Tabel 1. Perbedaan Pendekatan Kontekstual dengan Pendekatan Tradisional

\begin{tabular}{|c|c|c|}
\hline No. & CTL & Tradisonal \\
\hline 1. & $\begin{array}{l}\text { Menyandarkan pada memori spasial } \\
\text { (pemahaman makna) }\end{array}$ & Menyandarkan pada hafalan \\
\hline 2. & $\begin{array}{l}\text { Pemilihan informasi berdasarkan kebutuhan } \\
\text { siswa }\end{array}$ & Pemilihan informasi ditentukan oleh guru \\
\hline 3. & $\begin{array}{l}\text { Siswa terlibat secara aktif dalam proses } \\
\text { pembelajaran }\end{array}$ & Siswa secara pasif menerima informasi \\
\hline 4. & $\begin{array}{l}\text { Pembelajaran dikaitkan dengan kehidupan } \\
\text { nyata atau masalah yang disimulasikan }\end{array}$ & Pembelajaran sangat abstrak dan teoritis \\
\hline 5. & $\begin{array}{l}\text { Selalu mengkaitkan informasi dengan } \\
\text { pengetahuan yang telah dimiliki siswa }\end{array}$ & $\begin{array}{l}\text { Memberikan tumpukan informasi kepada } \\
\text { siswa sampai saatnya diperlukan }\end{array}$ \\
\hline 6. & $\begin{array}{l}\text { Cenderung mengintegrasikan beberapa } \\
\text { bidang }\end{array}$ & $\begin{array}{l}\text { Cenderung terfokus pada satu bidang (disiplin) } \\
\text { tertentu }\end{array}$ \\
\hline 7. & $\begin{array}{l}\text { Siswa menggunakan waktu belajarnya untuk } \\
\text { menemukan, menggali, berdiskusi, berpikir } \\
\text { kritis, atau mengerjakan proyek dan } \\
\text { pemecahan masalah (melalui kerja } \\
\text { kelompok) }\end{array}$ & $\begin{array}{l}\text { Waktu belajar siswa sebagian besar } \\
\text { dipergunakan untuk mengerjakan buku tugas, } \\
\text { mendengar ceramah, dan mengisi latihan yang } \\
\text { membosankan (melalui kerja individual) }\end{array}$ \\
\hline 8. & Perilaku dibangun atas kesadaran diri & Perilaku dibangun atas kebiasaan \\
\hline 9. & $\begin{array}{l}\text { Keterampilan dikembangkan atas dasar } \\
\text { pemahaman }\end{array}$ & Keterampilan dikembangkan atas dasar latihan \\
\hline 10. & $\begin{array}{l}\text { Hadiah dari perilaku baik adalah kepuasan } \\
\text { diri }\end{array}$ & $\begin{array}{l}\text { Hadiah dari perilaku baik adalah pujian atau } \\
\text { nilai (angka) rapor }\end{array}$ \\
\hline 11. & $\begin{array}{l}\text { Siswa tidak melakukan hal yang buruk } \\
\text { karena sadar hal itu keliru dan merugikan }\end{array}$ & $\begin{array}{l}\text { Siswa tidak melakukan sesuatu yang buruk } \\
\text { karena takut akan hukuman }\end{array}$ \\
\hline 12. & Perilaku baik berdasarkan motivasi intrinsik & Perilaku baik berdasarkan motivasi ekstrinsik \\
\hline 13. & $\begin{array}{l}\text { Pembelajaran terjadi di berbagai tempat, } \\
\text { konteks dan setting }\end{array}$ & Pembelajaran hanya terjadi dalam kelas \\
\hline 14. & $\begin{array}{l}\text { Hasil belajar diukur melalui penerapan } \\
\text { penilaian autentik. }\end{array}$ & $\begin{array}{l}\text { Hasil belajar diukur melalui kegiatan akademik } \\
\text { dalam bentuk tes/ujian/ulangan. }\end{array}$ \\
\hline
\end{tabular}

Sumber : Direktorat Pembinaan SMP (2006)

Pendekatan CTL memiliki tujuh komponen utama, yaitu konstruktivisme (constructivism), menemukan (inquiry), bertanya (austioning) masyarakat belajar (learning community), pemodelan (modelling), refleksi (reflection) dan penilaian yang sebenarnya (authentic assessment). Sebuah kelas dapat dikatakan menggunakan pendekatan CTL jika menerapkan ketujuh komponen tersebut dalam pembelajaran. CTL dapat diterapkan dalam kurikulum apa saja, bidang studi apa saja, dan kelas yang bagaimanapun keadaannya (Anonim, 2007).

Trianto (2010) menjelaskan bahwa konstruktivisme (constructivism) merupakan landasan berfikir (filosofi) pendekatan CTL, yaitu bahwa pengetahuan dibangun oleh manusia sedikit demi sedikit, yang hasilnya diperluas melalui konteks terbatas dan tidak sekonyong-konyong. Pengetahuan bukan seperangkat fakta-fakta, konsep, atau kaidah yang siap untuk diambil dan diingat. Siswa perlu dibiasakan untuk memecahkan masalah, menemukan sesuatu yang berguna bagi dirinya, dan bergelut dengan ide-ide. Guru tidak akan mampu memberikan semua pengetahuan kepada siswa. Siswa harus dapat mengkonstruksikan pengetahuan dalam diri sendiri. Esensi dari teori konstruktivis adalah ide bahwa siswa harus menemukan dan mentransformasikan suatu informasi kompleks ke situasi lain, dan apabila dikehendaki, informasi itu menjadi diri sendiri.

Menemukan merupakan bagian inti dari kegiatan pembelajaran berbasis CTL. Pengetahuan dan keterampilan yang diperoleh 
siswa diharapkan bukan hasil mengingat seperangkat fakta-fakta, tetapi hasil dari menemukan sendiri (Aunurrahman, 2009). Guru harus selalu merancang kegiatan yang merujuk pada kegiatan menemukan, apapun materi yang diajarkannya. Topik mengenai adanya macam menu makanan, sudah seharusnya ditemukan sendiri oleh siswa, bukan menurut buku. Nurhadi dan Senduk (2002) memaparkan bahwa siklus inkuiri adalah obsevasi (observation), bertanya (questioning), mengajukan dugaan (hyphotesis), pengumpulan data (data gathering), dan penyimpulan (conclusion).

Pengetahuan yang dimiliki seseorang, selalu bermula dari bertanya. Questioning merupakan strategi utama pembelajaran yang berbasis CTL. Bagi siswa, kegiatan bertanya merupakan bagian penting dalam melaksanakan pembelajaran yang berbasis inquiri, yaitu menggali informasi, mengkonfirmasikan apa yang sudah diketahui, dan mengarahkan perhatian pada aspek ynag belum diketahui.

Konsep learning community menyarankan agar hasil pembelajaran diperoleh dari kerja sama dengan orang lain. Hasil belajar diperoleh dari sharing antara teman, antar kelompok, dan antara yang tahu ke yang belum tahu (Nurhadi dan Senduk, 2002). Dalam kelas CTL, guru disarankan selalu melaksanakan pembelajaran dalam kelompok-kelompok belajar. Masyarakat belajar dapat terwujud apabila ada proses komunikasi dua arah.

Komponen CTL selanjutnya adalah pemodelan. Artinya dalam sebuah pembelajaran keterampilan atau pengetahuan tertentu, ada model yang dapat ditiru. Model itu dapat berupa cara mengoperasikan sesuatu, cara mengolah bumbu dalam memasak, contoh karya tulis, cara menulis, dan sebagainya. Contoh lainnya adalah guru memberi langkah cara mengerjakan sesuatu. Dengan begitu, guru memberi model tentang bagaimana cara belajar.

Refleksi juga bagian penting dalam pembelajaran dengan pendekatan CTL. Refleksi adalah cara berfikir tentang apa yang sudah kita lakukan di masa lalu (Nurhadi dan Senduk, 2002)
Siswa mengendapkan apa yang baru dipelajari sebagai struktur pengetahuan yang baru. Hal ini merupakan tahap pengayaan atau revisi dari pengetahuan sebelumnya. Refleksi merupakan respon terhadap kejadian, aktivitas, atau pengetahuan yang baru diterima (Depdiknas, 2003). Realisasinya berupa pernyataan langsung tentang apa yang diperoleh hari itu, catatan atau jurnal di buku mahasiswa berupa kesan dan saran mahasiswa mengenai pembelajaran hari itu, dan diskusi hasil karya.

Assessment adalah proses pengumpulan berbagai data yang dapat memberikan gambaran perkembangan belajar mahasiswa. Gambaran perkembangan belajar mahasiswa perlu di ketahui oleh guru agar dapat memastikan bahwa mahasiswa mengalami proses pembelajaran dengan benar. Karakteristik autentic assessment dilaksanakan selama dan sesudah proses pembelajaran berlangsung, dapat digunakan untuk formatif maupun sumatif, yang diukur adalah keterampilan dan performansi, bukan mengingat fakta, berkesinambungan, terintergrasi, dan dapat digunakan sebagai feed back (Depdiknas, 2003). Hal-hal yang dapat di gunakan sebagai dasar menilai prestasi mahasiswa adalah proyek atau kegiatan dan laporannya, pekerjaan rumah, kuis, karya tulis, presentasi atau penampilan siswa, demonstrasi, laporan, jurnal, hasil tes tulis, dan karya tulis.

\section{METODE}

Penelitian ini merupakan penelitian tindakan kelas dengan tujuan memperbaiki dan meningkatkan mutu pembelajaran sehingga dapat menghasilkan calon guru SMK bidang Tata Boga yang profesional. Metode ini diterapkan pada mahasiswa PT Boga Semester 6 yang mengikuti mata kuliah Restoran, di Jurusan PT Boga dan Busana, Fakultas Teknik, UNY. Teknik pengumpulan data dalam penelitian ini menggunakan metode tes untuk mengetahui prestasi belajar mahasiswa dan observasi untuk mengadakan pencatatan secara sistematis 
mengenai tingkah laku secara langsung kelompok ataupun individu, wawancara digunakan untuk mengungkap data tentang pelaksanaan pembelajaran Restoran melalui pendekatan kontekstual.

Instrumen dalam penelitian ini meliputi instrumen tes hasil belajar dan lembar observasi. Kriteria keberhasilan tindakan dilihat dari (1) meningkatnya aktivitas mahasiswa dalam PBM, (2) meningkatnya prestasi belajar mahasiswa. Untuk mengembangkan alat evaluasi tes, langkah-langkah yang ditempuh adalah (a) merumuskan tujuan pengukuran yang akan disusun, (b) membuat kisi-kisi, (c) membuat instrumen, (d) membuat lembar pengamatan, (e) penelaahan butir instrumen dan kriteria pengukuran, dan (f) uji coba instrumen. Untuk mengetahui validitas isi dan reliabilitas dilakukan dengan menggunakan rational judgement, yaitu meminta pertimbangan para ahli untuk menilai apakah butir-butir instrumen tersebut telah menggambarkan indikator variabel-variabel yang dimaksud atau belum.

Adapun pelaksanaan penelitian pada Semester Genap Tahun Akademik 2013/ 2014. Tahap-tahap penelitian tindakan yang melibatkan mahasiswa dan peneliti sebagai kolaborator ini adalah: (1) tahap persiapan berupa dialog awal untuk mengidentifikasi masalah, dan merumuskan permasalahan dan penyatuan ide untuk perbaikan pembelajaran Restoran; (2) tahap perencanaan meliputi menetapkan alternatif upaya dalam peningkatan kualitas pembelajaran Restoran, penentuan metode pembelajaran, dan penyusunan rancangan tindakan; (3) pelaksanaan tindakan berupa peneliti sebagai kolaborator menerapkan desain pembelajaran melalui pendekatan model pembelajaran kontekstual; (4) Observasi dan Monitoring, tahap ini dilakukan dalam upaya perbaikan proses pembelajaran dan perencanaan tindakan yang lebih kritis; (5) Refleksi berguna sebagai upaya memantapkan kegiatan atau tindakan untuk mengatasi permasalahan dengan memodifikasi perencanaan sebelumnya sesuai dengan hasil di lapangan; (6) Evaluasi dan revisi. Evaluasi dan revisi dilakukan untuk mengetahui keberhasilan tindakan yang telah dilakukan. Kriteria keberhasilan tindakan berdasarkan peningkatan aktivitas mahasiswa dalam PBM dan prestasi belajar mahasiswa (7) Kesimpulan hasil berupa pembuatan pelaporan hasil secara keseluruhan. Analisis data yang digunakan dalam penelitian ini adalah analisis deskriptif yang digunakan untuk menggambarkan pencapaian prestasi belajar mahasiswa. Perbedaan prestasi belajar awal sebelum dilaksanakan tindakan dan prestasi belajar akhir sesudah dilaksanakan tindakan diukur menggunakan perbedaan rerata skor pre test dan post-test.

\section{HASIL DAN PEMBAHASAN}

Dalam meningkatkan keaktifan dan pengetahuan mahasiswa pada pembelajaran, maka dibuat rencana mengenai proses pembelajaran yang akan dilaksanakan agar lebih menarik dan mahasiswa akan lebih memahami materi yang dipelajari. Dalam penjelasan tersebut solusi yang tepat sebagai upaya meningkatkan keaktifan dan pengetahuan mahasiswa dalam pembelajaran di kelas adalah dengan model pembelajaran CTL. Desain pembelajaran pada siklus I dan II ini diterapkan pada kompetensi konsep restoran dan membuat rancangan bisnis. Format penyampaian materi dilakukan melalui penjelasan materi, survey di industri, diskusi kelompok yang dilanjutkan dengan presentasi kelompok tentang hasil survey mengenai konsep restoran.

Perencanaan dilakukan dalam 2 siklus tindakan. Siklus I dilakukan dalam satu pertemuan dan siklus II dilakukan dalan dua pertemuan. Beberapa persiapan yang dilakukan peneliti sebelum melakukan tindakan adalah (1) membuat RPP, (2) menyusun lembar observasi, (3) membuat penugasan survey di industri dan diskusi, dan (4) menyusun soal tes individu yang akan diberikan kepada mahasiswa. Tes individu diberikan dalam 2 tahap. Tahap I berisi tentang konsep restoran, dan Tahap II 
berisi tentang perancangan bisnis, cara peyusunan, tujuan, manfaat.

Kegiatan pra siklus dilakukan untuk mengetahui kegiatan belajar mengajar restoran pada mahasiswa Pendidikan Teknik Boga. Hasil pengamatan dan kegiatan pra siklus yang dilakukan peneliti tersebut yaitu: mahasiswa masuk kelas pukul 07.10 WIB, selanjutnya dosen menjelaskan materi dengan metode ceramah, empat mahasiswa bertanya dan menanggapi pertanyaan dosen, masih terlihat ada mahasiswa yang tidak memperhatikan penjelasan dosen, peneliti memberikan tugas kepada mahasiswa untuk melakukan survey berkaitan dengan konsep restoran baik formal maupun non formal. Tugas untuk tiap kelompok adalah mengamati dan menganalisis Restoran formal dan non formal yang ada di industri (studi literatur dilanjutkan survey).

Pada analisis siklus 1, pelaksanaan tindakan yang dilakukan adalah sebagai berikut: (1) pelaksanaan tindakan pada pertemuan ke 1 siklus I, pengajar memberikan tugas survey kepada mahasiswa dalam bentuk kelompok untuk melakukan survey di Industri. Survey tersebut tentang konsep Restoran. (a) Peneliti sebagai pengajar membuka pelajaran dengan mengucapkan salam kemudian melakukan pemeriksaan presensi secara singkat, selanjutnya melakukan apersepsi (b) Tahap berikutnya pengajar menjelaskan materi pelajaran sesuai dengan kompetensi dasar (c) Mahasiswa mempresentasikan hasil survey tentang konsep restoran bersama kelompok masing-masing (d) Dosen memberikan tanggapan atas hasil survey dan presentasi mahasiswa (e) Kegiatan penutup: mahasiswa dibantu oleh dosen menyimpulkan hasil pembelajaran. (f) Dosen mengadakan tes individu berupa post-test, dan diakhiri dengan salam. Observasi keaktifan mahasiswa pada kegiatan pembelajaran restoran dengan model pembelajaran CTL siklus I dilaksanakan sesuai dengan kompetensi yang ingin dicapai seperti yang telah didesain. Pada siklus I ini keaktifan belajar mahasiswa masih kurang. Hal tersebut terlihat dalam Tabel 2 .

Tabel 2. Hasil Observasi Keaktifan Mahasiswa pada Siklus I

\begin{tabular}{|c|c|c|c|}
\hline No & Kegiatan Mahasiswa & Jumlah Mahasiswa & $(\%)$ \\
\hline \multirow[t]{2}{*}{1.} & $\begin{array}{l}\text { Memperhatikan penjelasan materi dari dosen dengan sungguh- } \\
\text { sungguh dan penuh keyakinan }\end{array}$ & 19 & $47,5 \%$ \\
\hline & Mencatat materi yang disampaikan dosen, menyimak dengan baik & & \\
\hline \multirow[t]{3}{*}{2.} & Menjawab pertanyaan: & & \\
\hline & a. Mendefinisikan istilah berdasarkan teori & 10 & $25 \%$ \\
\hline & b. Memberikan contoh dalam kehidupan sehari-hari dan industri & & \\
\hline \multirow[t]{3}{*}{3.} & Mengemukakan pendapat: & 5 & $12.5 \%$ \\
\hline & Mendefinisikan istilah-istilah sesuai teori & & \\
\hline & Memberikan contoh sesuai pengetahuan yang dimiliki & & \\
\hline 4. & $\begin{array}{l}\text { Presentasi kelompok (mampu mengkomunikasikan hasil pikiran } \\
\text { dan penemuan secara lisan dan tertulis) }\end{array}$ & 6 & $15 \%$ \\
\hline
\end{tabular}

Tabel 2 menunjukkan sebanyak 47,5\% mahasiswa memperhatikan penjelasan dosen, $25 \%$ mahasiswa menjawab pertanyaan dengan memberikan contoh dalam kehidupan seharihari, $12,5 \%$ mahasiswa mengemukakan pendapat dan $15 \%$ mahasiswa melakukan presentasi. Tes hasil belajar dilaksanakan untuk mengetahui tingkat pengetahuan mahasiswa dalam pembelajaran restoran. Hasil tes belajar tersebut dapat dilihat pada Tabel 3.

Tabel 3. Hasil Tes Tingkat Pengetahuan Mahasiswa pada Siklus I

\begin{tabular}{cccc}
\hline No & \multicolumn{1}{c}{ Nilai Hasil Tes } & Jumlah Mahasiswa & $(\%)$ \\
\hline 1. & $90-100$ & 4 & $10 \%$ \\
2. & $75-89$ & 20 & $50 \%$ \\
3. & $60-74$ & 6 & $15 \%$ \\
4. & $0-59$ & 10 & $25 \%$ \\
Jumlah Total Mahasiswa & 40 & \\
\hline
\end{tabular}


Tabel 3 di atas menunjukkan bahwa 10\% mahasiswa memperoleh nilai amat baik, 50\% mahasiswa memperoleh nilai baik, $15 \%$ mahasiswa memperoleh nilai cukup, 10\% mahasiswa memperoleh nilai kurang. Dari hasil tindakan satu pertemuan tersebut, dapat terlihat penerapan 7 komponen utama dengan menerapkan 5 konsep pembelajaran CTL yaitu: (1) kegiatan konstruktivisme terlihat pada saat dosen menjelaskan tentang arti penting dari mempelajari ruang lingkup usaha restoran. Dua orang mahasiswa menjelaskan fungsi dari mengetahui ruang lingkup usaha restoran sesuai dengan pengetahuan yang dimiliki. Satu orang mahasiswa lain menjelaskan bahwa ruang lingkup restoran meliputi restoran formal dan non formal. Satu orang mahasiswa lain menjelaskan bahwa ruang lingkup usaha restoran adalah meliputi usaha pelayanan makanan dan minuman yang dilakukan secara formal dan non formal. Dari dua pendapat mahasiswa tersebut dapat diambil kesimpulan bahwa ruang lingkup usaha restoran meliputi pelayanan makanan dan minuman yang dilakukan di restoran formal maupun restoran non formal; (2) kegiatan bertanya terlihat pada saat dosen menanyakan tentang apa yang dilakukan mahasiswa terhadap ruang lingkup usaha restoran. Kegiatan bertanya yang lain dilakukan oleh dua orang mahasiswa; (3) kegiatan inqury terlihat saat mahasiswa melakukan survey di lingkungan industri terutama di restoran formal dan non formal. Mahasiswa dibagi dalam 4 kelompok besar yang mempunyai tugas sebagai berikut: kelompok 1 dan 2 survey di restoran formal sedangkan kelompok 3 dan 4 survey di restoran non formal, Kemudian tiap kelompok mengidentifikasi ruang lingkup usaha restoran, ciri-ciri, dan karakteristik jenis serta disimpulkan. Hasil survey menunjukkan bahwa di setiap restoran mempunyai perbedaan dalam pengelolaan, ciri dan karakteristik sesuai dengan manajemen masing-masing restoran.

Kegiatan refleksi terlihat pada saat mahasiswa dibantu dosen untuk menyimpulkan kembali tentang materi yang disampaikan yaitu tentang ruang lingkup usaha restoran. Peneliti menilai prestasi belajar mahasiswa dengan berbagai cara yang meliputi aspek afektif, kognitif, dan psikomotor. Aspek afektif meliputi sikap dan tingkah laku mahasiswa selama mengikuti pembelajaran. Aspek kognitif di tunjukkan dengan tes pengetahuan mahasiswa pada akhir pembelajaran. Aspek psikomotor ditunjukkan dengan penampilan mahasisawa ketika presentasi dan bertanya. Motivasi mahasiswa untuk mengikuti pembelajaran masih kurang. Hal tersebut ditunjukkan dengan kegiatan belajar mengajar yang masih pasif sehingga berdampak pada hasil belajar yang belum memuaskan ditunjukkan dengan 12,9\% mahasiswa mendapatkan nilai dengan kategori kurang.

Setelah pelaksanaan pembelajaran dengan model CTL, selanjutnya dilakukan refleksi pada siklus I terhadap pembelajaran restoran. Dosen mendiskusikan bersama hasil pengamatan yang dilakukan selama pelaksanaan tindakan dan melakukan evaluasi. Berdasarkan data hasil pelaksanaan tindakan, ditemukan permasalahan yaitu sebagai berikut: (1) mahasiswa kurang memperhatikan penjelasan dosen, (2) tidak semua mahasiswa mencatat materi yang disampaikan dosen, (3) masih ada mahasiswa yang berbicara sendiri pada saat pelajaran berlangsung, (4) partisipasi mahasiswa saat pembelajaran berlangsung kurangn, (5) siswa masih bertanya dengan teman yang lain saat melakukan tes individu meskipun peringatan sudah dilakukan.

Berdasarkan hasil observasi di atas dapat disimpulkan bahwa tujuan pembelajaran yang ingin dicapai dari kegiatan pembelajaran belum tercapai sehingga perlu dilanjutkan pada siklus berikutnya dengan mengadakan beberapa perbaikan. Adapun usaha perbaikan tersebut antara lain dengan menggunakan metode pembelajaran yang berbeda sehingga siswa lebih aktif dan dapat memahami materi yang diberikan. Pada analisis siklus II, pelaksanaan tindakan pertemuan diperoleh hasil sebagai 
berikut: (1) dosen membuka pelajaran dengan mengucapkan salam kemudian melakukan pemeriksaan daftar presensi secara singkat, (2) dosen menyampaikan apersepsi dan tujuan pembelajaran, (3) dosen menjelaskan materi sesuai kompetensi dasar yaitu menerapkan konsep lingkungan hidup dengan materi tentang limbah, (4) dosen mengelompokan mahasiswa ke dalam 4 kelompok besar kemudian setiap kelompok berdiskusi tentang penyusunan business plan usaha restoran, (5) presentasi kelompok hasil diskusi dilakukan di depan dosen dan siswa yang lain kemudian ditanggapi oleh kelompok lain yang berupa tanggapan atau pertanyaan, (6) dosen menutup pelajaran sambil memotivasi siswa untuk lebih giat dalam menyelesaikan tugas yang dilanjutkan pada pertemuan berikutnya.

Pelaksanaan Tindakan Pertemuan ke 2 siklus II, diperoleh hasil berikut: (1) dosen membuka pelajaran dengan mengucapkan salam kemudian melakukan pemeriksaan daftar presensi secara singkat kemudian mengulas materi pembelajaran yang telah dijelaskan pada pertemuan sebelumnya, (2) pada pertemuan kedua ini presentasi hasil diskusi dilanjutkan untuk kelompok berikutnya, (3) mahasiswa memberikan tanggapan dan pertanyaan terhadap kelompok yang melakukan presentasi, (4) dosen memberikan ulasan terhadap hasil presentasi, (5) kegiatan penutup: mahasiswa dibantu dosen menyimpulkan materi pembelajaran, (6) dosen mengadakan tes individu, (7) mahasiswa menyampaikan kesan dan pesan terhadap pembelajaran yang telah berlangsung, dan (8) pengajar mengucapkan salam untuk menutup pelajaran. Selama kegiatan pembelajaran berlangsung diadakan observasi secara langsung oleh dosen. Kegiatan belajar mengajar pada siklus ke II sudah menunjukan kemajuan. Mahasiswa sudah mulai berperan secara aktif dalam pembelajaran. Adapun hasil pengamatan aktivitas mahasiswa pada siklus II dapat dilihat pada Tabel 4 sebagai berikut:

Tabel 4. Hasil Observasi Keaktifan Proses pada Siklus II

\begin{tabular}{|c|c|c|c|}
\hline No & Kegiatan Mahaiswa & $\begin{array}{c}\text { Jumlah } \\
\text { Mahasiswa }\end{array}$ & $(\%)$ \\
\hline 1. & $\begin{array}{l}\text { Memperhatikan penjelasan materi dari dosen dengan sungguh- } \\
\text { sungguh dan penuh keyakinan, Mencatat materi yang disampaikan } \\
\text { dosen, menyimak dengan baik }\end{array}$ & 40 & $100 \%$ \\
\hline 2. & $\begin{array}{l}\text { Menjawab pertanyaan: } \\
\text { a. Mendefinisikan istilah berdasarkan teori } \\
\text { b. Memberikan contoh dalam kehidupan sehari-hari dan industri }\end{array}$ & 15 & $37,5 \%$ \\
\hline 3. & $\begin{array}{l}\text { Mengemukakan pendapat: Mendefinisikan istilah-istilah sesuai } \\
\text { teori, dan Memberikan contoh sesuai pengetahuan yang dimiliki }\end{array}$ & 25 & $62.5 \%$ \\
\hline 4. & $\begin{array}{l}\text { Presentasi kelompok (mampu mengkomunikasikan hasil pikiran } \\
\text { dan penemuan secara lisan dan tertulis) }\end{array}$ & 10 & $25 \%$ \\
\hline
\end{tabular}

Tabel 4 menunjukkan bahwa keaktifan mahasiswa pada pembelajaran restoran sebanyak $100 \%$ mahasiswa memperhatikan penjelasan dosen. Kegiatan menjawab pertanyaan dosen sebanyak 37,5\%. Kegiatan mengemukakan pendapat sebanyak $62,5 \%$. Kegiatan diskusi kelompok atau presentasi sebanyak $25 \%$. Tes tingkat pengetahuan mahasiswa siklus II pada mata kuliah restoran. Hasil tes belajar mahasiswa pada siklus II pada terlihat pada Tabel 5 berikut:

Tabel 5. Hasil Tes Tingkat Pengetahuan pada Siklus II

\begin{tabular}{cccc}
\hline No & Nilai Hasil Tes & Jumlah Siswa & Prosentase (\%) \\
\hline 1. & $90-100$ & 25 & $62,5 \%$ \\
2. & $75-89$ & 15 & $37,5 \%$ \\
3. & $60-74$ & - & - \\
4. & $0-59$ & - & - \\
& Jumlah Total Mahasiswa & 40 & \\
\hline
\end{tabular}


Tabel 5 menunjukkan $62,5 \%$ mahasiswa mendapatkan nilai amat baik, 37,5\% mahasiswa mendapatkan nilai baik. Peneliti menilai prestasi belajar mahasiswa meliputi 3 aspek yaitu aspek afektif, kognitif, dan psikomotor. Aspek afektif meliputi sikap dan tingkah laku mahasiswa selama mengikuti pembelajaran. Aspek kognitif ditunjukkan oleh tes tingkat pemahaman mahasiswa. Aspek psikomotor ditunjukkan oleh penampilan mahasiswa ketika melakukan presentasi, diskusi, bertanya dan mengerjakan tugas yang diberikan dosen. Motivasi mahasiswa dalam mengikuti pembelajaran meningkat. Mahasiswa sudah berperan secara aktif dalam pembelajaran hal tersebut terlihat dari jumlah mahasiswa yang mengemukakan pendapat, bertanya maupun menjawab pertanyaan dari pengajar. Hal tersebut berdampak pada hasil belajar mahasiswa yang sangat memuaskan karena $64,5 \%$ mahasiswa mendapatkan nilai istimewa.

Refleksi tindakan kegiatan belajar mengajar pada siklus II telah menunjukkan kemajuan, mahasiswa mulai lebih aktif di banding pada siklus I. Mahasiswa sudah mulai terbiasa dengan pola pembelajaran dengan model pembelajaran CTL yang dilakukan pengajar. Pertemuan pada siklus II ini hampir semua aktivitas, pengetahuan, dan pemahaman mahasiswa terhadap materi pelajaran mengalami peningkatan. Hal ini terlihat dari mahasiswa lebih aktif dalam diskusi, menanggapi, bertanya, kemampuan pemecahan masalah, presentasi, dan hasil belajar mahasiswa lebih baik.

Hasil penelitian tindakan kelas dari dua siklus dengan standar kompetensi ruang lingkup usaha restoran dan penyusunan rancangan bisnis, melalui penerapan model pembelajaran CTL dapat diklasifikasikan sebagai berikut: (1) Pelaksanaan kegiatan pembelajaran penerapan model pembelajaran CTL di Program Studi PT Boga dapat berjalan dengan baik. Pada awal penerapan, mahasiswa belum aktif dalam kegiatan pembelajaran dan tingkat pemahaman masih rendah, tetapi pada pertemuan berikutnya mahasiswa sudah terlihat lebih aktif di kelas dan tingkat pengetahuan dan pemahaman meningkat. Pada setiap siklus, pengajar selalu mengadakan pembaharuan dalam metode pembelajaran yang digunakan sesuai dengan konsep model pembelajaran CTL. Hal tersebut dilakukan agar mahasiswa tidak bosan dan untuk memberikan suasana baru. Penggunaan beberapa konsep pembelajaran CTL diharapkan dapat meningkatkan keaktifan, pengetahuan, dan pemahaman mahasiswa terhadap pembelajaran Restoran. (2) Keaktifan dan tingkat pengetahuan mahasiswa dan pemahaman mahasiswa berbeda-beda dalam setiap siklusnya. Pada siklus I, sebagian mahasiswa belum aktif dalam kegiatan pembelajaran. Hal tersebut dapat dilihat dari hasil pengamatan dan tes hasil belajar yang dilakukan yaitu sebanyak 93,5\% mahasiswa memperhatikan penjelasan dosen. Mahasiswa bertanya kepada dosen sebanyak 16,1\%. Mahasiswa menjawab pertanyaan dengan memberikan contoh dalam kehidupan harian sebanyak 32,3\%. Mahasiswa melakukan presentasi sebanyak $19,4 \%$. Hasil belajar mahasiswa pada siklus I sebanyak 12,9\% mahasiswa memperoleh nilai amat baik, 64,5\% mahasiswa memperoleh nilai baik, 19,4\% mahasiswa memperoleh nilai cukup, 3,2\% mahasiswa memperoleh nilai kurang.

Pada siklus II keaktifan, pengetahuan, dan pemahaman mahasiswa secara keseluruhan meningkat apabila dibandingkan dengan siklus sebelumnya. Hal tersebut terlihat sebanyak $100 \%$ mahasiswa memperhatikan penjelasan dosen. Kegiatan bertanya kepada dosen sebanyak 18,8\% mahasiswa. Kegiatan menjawab pertanyaan dosen sebanyak $32,2 \%$ mahasiswa. Kegiatan mengemukakan pendapat sebanyak 15,6\% mahasiswa. Kegiatan diskusi kelompok dilakukan oleh $100 \%$ mahasiswa. Kegiatan memberikan pendapat dan solusinya sebanyak $78,1 \%$ mahasiswa. Kegiatan presentasi sebanyak $38,7 \%$ mahasiswa. Hasil belajar mahasiswa pada siklus II adalah $64,5 \%$ mahasiswa mendapatkan 
nilai amat baik, dan 35,5\% mendapatkan nilai baik. Secara keseluruhan penerapan model pembelajaran CTL mampu untuk meningkatkan keaktifan, pengetahuan, serta pemahaman mahasiswa dalam belajar. Suasana kelas menjadi aktif pada saat pengajar menjelaskan materi pelajaran. Meningkatnya keaktifan mahasiswa berpengaruh pada meningkatnya pengetahuan dan pemahaman mahasiswa dalam pembelajaran
Restoran. Pada siklus I, hasil belajar mahasiswa belum memuaskan karena nilai rata-rata kelas dari mengerjakan soal adalah $12,9 \%$ dengan kategori amat baik. Hasil belajar pada siklus II sangat memuaskan karena nilai rata-rata kelas yang dicapai 64,5\% mahasiswa dengan kategori amat baik, seperti yang disajikan pada Tabel 6 di bawah ini.

Tabel 6. Perbandingan Keaktifan Belajar Mahasiswa pada Siklus I dan Siklus II

\begin{tabular}{|c|c|c|c|}
\hline No & Kegiatan Mahasiswa & (\%) Siklus I & (\%) Siklus II \\
\hline 1. & $\begin{array}{l}\text { Memperhatikan penjelasan materi dari guru dengan sungguh-sungguh } \\
\text { dan penuh keyakinan (mencatat materi yang disampaikan guru, } \\
\text { menyimak dengan baik) }\end{array}$ & $93,5 \%$ & $100 \%$ \\
\hline 2. & Bertanya kepada guru (bertanya tentang materi yang kurang jelas) & $16,1 \%$ & $18,8 \%$ \\
\hline 3. & $\begin{array}{l}\text { Menjawab pertanyaan: } \\
\text { a. Mendefinisikan istilah berdasarkan teori }\end{array}$ & & \\
\hline & b. Memberikan contoh dalam kehidupan sehari-hari & $32,2 \%$ & $32,2 \%$ \\
\hline 4. & $\begin{array}{l}\text { Mengemukakan pendapat: } \\
\text { a. Mendefinisikan istilah-istilah sesuai teori } \\
\text { b. Memberikan contoh sesuai pengetahuan yang dimiliki }\end{array}$ & - & $15,6 \%$ \\
\hline 5. & $\begin{array}{l}\text { Kerjasama dalam kelompok } \\
\text { a. Berdiskusi dengan teman sekelompok maupun teman dalam } \\
\text { kelompok lain tentang permasalahan }\end{array}$ & - & $100 \%$ \\
\hline & b. Memberikan pendapat atas masalah dan solusinya & & $80,6 \%$ \\
\hline 6. & $\begin{array}{l}\text { Presentasi kelompok (mampu mengkomunikasikan hasil pikiran dan } \\
\text { penemuan secara lisan dan tertulis) }\end{array}$ & $19,4 \%$ & $38,7 \%$ \\
\hline
\end{tabular}

Penerapan model pembelajaran CTL pada mata kuliah Restoran ini dapat ditemukan peningkatan keaktifan dan tingkat pengetahuan serta pemahaman mahasiswa. Selama kegiatan pembelajaran berlangsung mahasiswa dapat bertanya, berdiskusi, dan saling bertukar pikiran dengan teman. Mahasiswa lebih bersemangat dalam mengikuti pembelajaran Restoran karena menggunakan metode pembelajaran yang berbeda sehingga kegiatan pembelajaran tidak membosankan dan peningkatan kualitas hasil belajar dapat dipaparkan dalam Tabel 7.

Tabel 7. Perbandingan Hasil Belajar Mahasiswa Siklus I dan Siklus II

\begin{tabular}{lll}
\hline Nilai Hasil Tes & (\%) Siklus I & (\%) Siklus II \\
\hline $90-100$ & $12,9 \%$ & $64,5 \%$ \\
$74-89$ & $64,5 \%$ & $35,5 \%$ \\
$60-75$ & $19,4 \%$ & - \\
$0-59$ & $3,2 \%$ & - \\
\hline
\end{tabular}

Faktor-faktor yang lain yang berpengaruh terhadap prestasi mahasiswa belum dapat di ungkap dalam penelitian. Hal ini disebabkan adanya keterbatasan waktu dan kajian penelitian.

\section{SIMPULAN}

Penelitian tindakan kelas yang telah dilaksanakan peneliti berlangsung dalam dua siklus. Setiap siklus mempunyai pencapaian keaktifan dan tingkat pengetahuan mahasiswa yang berbeda-beda. Berdasarkan hasil penelitian dan pembahasan yang telah dilakukan hasil penelitian ini dapat disimpulkan sebagai berikut: (1) Tingkat keaktifan siswa pada pembelajaran Restoran meningkat. Hal tersebut dapat dilihat dari data siklus I, Mahasiswa memperhatikan penjelasan dosen sebanyak 47,5\%. Mahasiswa menjawab pertanyaan dengan memberikan contoh dalam kehidupan sehari-hari sebanyak 
25\%. Mahasiswa mengemukakan pendapat sebanyak $12,5 \%$ dan mahasiswa melakukan presentasi sebanyak $15 \%$. Sedangkan pada data siklus II, keaktifan belajar siswa berupa kegiatan memperhatikan penjelasan dosen meningkat sebesar 52,5\%, menjawab pertanyaan naik $12,5 \%$, mengemukakan pendapat meningkat $50 \%$, dan kegiatan presentasi meningkat $10 \%$. (2) Tingkat pengetahuan dan pemahaman mahasiswa terhadap materi pembelajaran Restoran meningkat. Hasil belajar mahasiswa pada siklus I sebanyak $10 \%$ mahasiswa memperoleh nilai amat baik, 50\% mahasiswa memperoleh nilai baik, $15 \%$ mahasiswa memperoleh cukup, dan $25 \%$ mahasiswa memperoleh nilai kurang. Hasil belajar siswa pada siklus II adalah $62,5 \%$ mahasiswa mendapatkan nilai amat baik dan 37,5\% mahasiswa mendapatkan nilai baik. Berdasarkan data tersebut dapat disimpulkan bahwa tingkat pengetahuan mahasiswa terhadap mata Kuliah Restoran meningkat sebesar $52,5 \%$ dengan kategori nilai amat baik.

\section{DAFTAR RUJUKAN}

. 2007. Pendekatan Kontekstual (Contextual Teaching and Learning). Tersedia di http://www.geocities.com. Diakses pada tanggal 15 Agustus 2007

Aunurrahman. 2009. Belajar dan Pembelajaran. Bandung: Alfa Beta
Depdiknas. 2003. Pendekatan Kontekstual. Jakarta: Depdiknas

Depdiknas. 2007. Revitalisasi Pendidikan Profesional Guru: Naskah Akademik. Jakarta: Ditjen Dikti Depdiknas

Dewey, J. 1916. Democracy and Education. New York: Mc Millan

Direktorat Pembinaan Sekolah Menengah Pertama. 2006. Pengembangan Model Pembelajaran yang Efektif. Direktorat Jenderal Pendidikan Dasar dan Menengah. Depdiknas. Diakses pada tanggal 15 Agustus 2007

Nurhadi dan Agus Gerrad Senduk. 2002. Pembelajaran Kontestual (Contextual Teaching and Learning/ CTL) dan Penerapannya dalam KBK. Malang: Universitas Negeri Malang

Toharudin, Uus. 2005. Kompetensi Guru dalam Strategi Ajar. Diakses dari http://www. pikiranrakyat.com. pada tanggal 15 Agustus 2007

Trianto. 2010. Mendesain Model Pembelajaran Inovatif-Progresif: Konsep, Landasan, dan Implementasinya pada Kurikulum Tingkat Satuan Pendidikan (KTSP). Jakarta: Kencana 